\title{
NYHEDSFORMIDLING OG FRYGT FOR KRIMINALI- TET I REYKJAVIK: ÆNDRING I TRYGHED I 2001
}

\author{
Af Professor, Ph.D. Helgi Gunnlaugsson, og sociolog, M.A. RanNVEig \\ PÓRISDÓTTIR
}

This article examines perceptions of safety in the downtown area of Reykjavik based on two public surveys conducted during the summer and fall of 2001. The sense of safety reported by respondents increased markedly over this time. In the summer, less than one-third of the respondents felt "rather" or "very safe" while walking alone late at night in the downtown area. Yet by the fall, the percentage of respondents reporting low fear levels had increased to more than forty percent. To help shed light on this change, press reports on the downtown area were analysed during these two time periods. Based on a content analysis of news headlines in the largest local daily, it appears that reports in the fall were much more positive than in the summer. While there may be other explanations for the change in perceived safety, we argue that the focus of the mass media may, at least in some cases, influence the public's perception of crime. *

I de sidste årtiers kriminologi har undersøgelser af frygt eller angst for kriminalitet og af oplevelsen af tryghed i lokalsamfundet været fremtrædende. Sådanne undersøgelser er meget vigtige, bl.a. fordi de har påvist, at frygt for kriminalitet er betydeligt mere udbredt en den reelle risiko for at blive offer for en forbrydelse (Zedner, 1997). Undersøgelserne har vist, at det er meget mere og andet end forekomsten af kriminalitet, der har indflydelse på den enkeltes tryghedsfølelse, og det er derfor ikke altid tilstrækkeligt at mindske kriminalitetsniveauet for at mindske frygten for kriminalitet (se bl.a. Balvig, 1990). Tilsyneladende kan også miljøer, der bærer præg af forsømmelighed og social opløsning, øge beboernes frygt (Lewis og Salem, 1986).

Mediernes nyhedsformidling om forbrydelser har formentlig også indflydelse på befolkningens frygt og bekymring for kriminalitet, især hvis der på dramatisk måde fokuseres på enkelte meget grove tilfælde, hvor almindelige borgere indblandes i forbrydelsen uden nogen synlig grund (Gunnlaugsson, 1996; Rosenbaum og Heath, 1990).

Frygt for kriminalitet viser sig at variere betydeligt mellem forskellige befolkningsgrupper. Undersøgelser tyder på, at frygt for kriminalitet først og

* Title in English: Mass Media and Fear of Crime in Reykjavik: Changes in Perceived Safety During 2001. Original in Danish. 
fremmest synes at plage beboere i tæt bebyggede områder, ikke mindst i afgrænsede områder såsom bykerner (Ollenburger, 1981). Generelt finder disse undersøgelser, at til trods for, at kvinder og ældre mennesker sjældnere end andre er ofre for forbrydelser, så er frygt for kriminalitet større i disse befolkningsgrupper end blandt mænd og yngre mennesker (se bl.a. Clemente og Kleiman, 1976). Nogle kriminologer har dog sat spørgsmålstegn ved, om der er mere udbredt frygt hos ældre (Ferraro, 1995).

Undersøgelser har endvidere vist, at de grupper, der erfaringsmæssigt hyppigt er ofre for forbrydelser, såsom fattige og minoritetsgrupper, frygter kriminalitet mere end andre (Skogan og Maxfield, 1981). Fælles for disse grupper er en følelse af at være værgeløse over for forbrydelser. Deres lavere sociale status kan være med til at øge frygten for kriminalitet og at mindske tryghedsfølelsen.

Forbrydelser forvolder unægteligt skade, men konsekvenserne rækker meget videre end selve skaderne og kan vise sig som frygt, der kan indvirke på menneskers livsvilkår og generelle velbefindende. Skønt frygten for kriminalitet ikke altid er realistisk, kan den alligevel øge angsten for fremmede og det ukendte og afskrække mennesker fra at færdes på offentlige steder og på den måde have indflydelse på vores liv. Frygt for kriminalitet kan endvidere føre til, at man låser døre og vinduer, køber dyre sikkerhedssystemer og går til kursus i selvforsvar, og det kan indebære, at det offentlige investerer i øget gadebelysning og $\mathrm{i}$ installation af overvågningskameraer. Undersøgelser på dette område er derfor af stor betydning, ikke kun for at kortlægge fordelingen af frygten, men også for at belyse, hvad det er, der forårsager frygten, og for at pege på muligheder til at afhjælpe situationen.

\section{Den islandske undersøgelse}

Undersøgelsen, som præsenteres her, giver et indblik i nogle aspekter omkring frygt for kriminalitet og menneskers tryghedsfølelse. Tryghedsfølelsen hos beboere i Reykjavik blev undersøgt to gange i løbet af 2001, og resultatet af disse undersøgelser er sammenholdt med massemediernes omtale af bl.a. kriminalitet i samme tidsrum. Vi har forsøgt at danne os et billede af, om frygt for kriminalitet har indflydelse på beboernes færden i Reykjavik centrum, og om massemediernes omtale af kriminalitet influerer på menneskers tryghedsfølelse. Undersøgelserne er gennemført dels kort før terrorangrebet på USA den 11. september $2001 \mathrm{og}$ dels kort herefter. I Danmark viste det sig, at danskernes bekymring for vold og kriminalitet faldt ganske kraftigt efter terrorangrebet, og spørgsmålet er, om vi kan se en lignende effekt i Island. Det må dog bemærkes, at vi beskæftiger os med tryghed og frygt for kriminalitet, hvilket ikke er helt det samme som bekymring for vold og kriminalitet, som man har beskæftiget sig med i Danmark (Clausen, 2002a og b).

Reykjaviks centrum består af et relativt lille og afgrænset område, hvor man finder langt de fleste af hovedstadsområdets værtshuse og restauranter. Hoved- 
stadsområdet rummer ca. to tredjedele af Islands befolkning, og centrum er derfor landets største samlede område for forlystelseslivet. I weekenderne strømmer mennesker til centrum, især den yngre generation. Det er ikke ualmindeligt, at der opstår køer ved de populæreste steder, og det sker, at der udbryder tumulter, der resulterer i voldshandlinger. Massemedierne overvåger som regel centrum ret intensivt, og deres beskrivelser af hændelser kan til tider være meget dramatiske. Mediernes interesse for at overvåge begivenhederne i centrum synes dog at variere noget: I visse perioder er midtbyen i mediernes brændpunkt og i visse perioder ikke. Spørgsmålet er, om massemediernes vekslende prioriteringer har indvirkning på tryghedsfølelsen hos mennesker i Reykjavik og på menneskers færden i midtbyen.

\section{Metoder og data}

Resultaterne bygger på to telefonundersøgelser foretaget af IM-Gallup, den første i sommeren $2001 \mathrm{og}$ den anden i efteråret 2001. Endvidere baseres undersøgelsen på data fra en gennemgang af nyheder og artikler om Reykjaviks midtby i det islandske dagblad Morgunbladid. Nyhederne er grupperet efter, om de var negative, positive eller neutrale. Nyheder er grupperet som negative, når de handler om vold og anden kriminalitet, og som positive, når de handler om fx nye spændende projekter i midtbyen og kulturbegivenheder. Neutrale nyheder vedrører almindelige meddelelser m.v.

I den første undersøgelse, der blev gennemført i perioden 26. juni til 25. juli 2001, blev der rettet henvendelse til 2700 repræsentativt udvalgte personer i alderen 18 til 80 år med bopæl i Reykjaviks politikreds. Sigtet med denne undersøgelse var også at analysere forholdene i forskellige boligområde i Reykjavik, hvorfor undersøgelsespopulationen måtte være ganske stor. Undersøgelsen blev lavet i samarbejde med politimesteren i Reykjavik, Islands Justitsministeriet, Institut for Urban Studies og Reykjavik kommunen. Af de 2700 personer valgte 1729 at deltage $i$ undersøgelsen, hvilket giver en svarprocent på 67, som alment anses for at være en tilfredsstillende høj svarprocent. I den anden undersøgelse, som blev gennemført i perioden 2. oktober til 14. november 2001, blev der rettet henvendelse til færre personer, nemlig i alt 1284 repræsentativt udvalgte personer med bopæl i Reykjaviks politikreds. Det er det antal personer, som almindeligvis indgår i Gallupundersøgelser i Reykjavik. Af de 1284 personer deltog 802 , svarende til 62 procent. Bortfaldsanalyser viser, at deltagere i begge undersøgelser på tilfredsstillende måde afspejler befolkningen mht. køn, alder og erhverv, hvorfor det må formodes, at undersøgelserne giver et troværdigt billede af befolkningens holdninger og vurderinger.

Som sagt er massemediernes behandling af begivenhederne i Reykjavik centrum analyseret ved at gennemgå artikler m.v. om emnet i Morgunbladids databank. Morgunbladid er det langt største dagblad i Island, og omtrent 70 procent af beboere i Reykjavik læser denne avis hver dag. I søgning efter artikler er det 
anvendte søgeord 'bycentrum', og alle artikler, der belyser forhold i Reykjaviks centrum, er taget med i undersøgelsen. Vurderingen af, om artiklens omtale er positiv, negativ eller neutral er i de fleste tilfælde baseret på overskriftens ordlyd, men en del artikler er blevet læst mere grundigt for at vurdere indholdet.

Artiklerne deles op i tre perioder: 25 . maj til 25. juli, 26. juli til 12. september og 13. september til 13. november. Analysen må tages med forbehold, da den kun inkluderer ét massemedie. Ligeledes må man huske på, at nyhederne er på redaktionens ansvar, som givetvis foretager en vis udvælgelse af avisstof. Overskrifterne er også gerne farvet at redaktionens holdning. Morgunbla $\partial \mathrm{i} \partial$ burde dog genspejle den til enhver tid aktuelle debat i samfundet og således give et fingerpeg om, hvad er i fokus, og om den generelle holdning til disse emner.

\section{Resultater}

Figur 1 viser deltagernes vurdering af egen tryghed ved at færdes alene om natten i Reykjaviks centrum. Undersøgelsen viser, at der sker en ændring i vurderingen af tryghed fra sommer- til efterårsundersøgelsen. I sommerundersøgelsen svarede $32 \%$, at de følte sig meget eller temmelig trygge ved at færdes alene i centrum om natten, men det i efterårsundersøgelsen drejer sig om $42 \%$. Denne vækst i andelen, der føler sig trygge, er statistisk signifikant. Omvendt svarede knap $58 \%$ om sommeren, at de følte sig meget eller temmelig utrygge ved at færdes alene i centrum om natten, men i efterårsundersøgelsen er tallet på kun knap 46\%. I begge tilfælde er forskellen betydelig ( $<<0,05$ ), og ændringen er også statistisk signifikant, når køn og alder holdes konstant. Ser man nærmere på figur 1, er det bemærkelsesværdigt, at ændringerne mellem de to perioder er størst hos de grupper, der føler sig meget utrygge eller meget trygge.

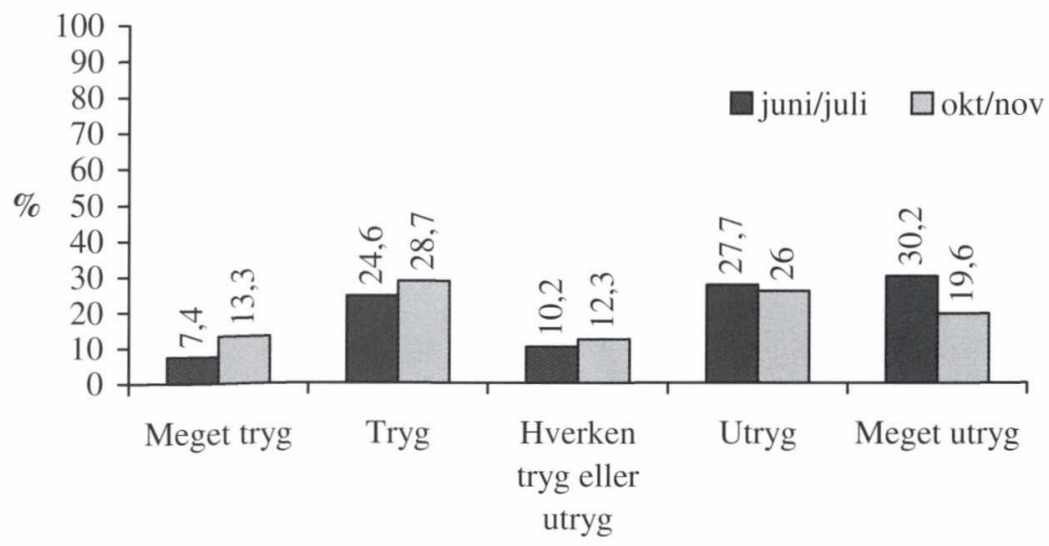

Figur 1. Hvor tryg eller utryg føler du dig ved at fardes alene om natten $i$ Reykjaviks centrum? Svar fordelt efter undersøgelsestidspunkt. Procent. 
For nærmere at belyse spørgsmålet om frygt for kriminalitet blev deltagerne spurgt, om de havde færdes alene om natten i Reykjaviks centrum inden for de seneste 12 måneder. Det siges nemlig ofte, at frygt for kriminalitet er størst hos de mennesker, der sjældent går ud. Undersøgelsen viser, at godt $38 \%$ af deltagerne i sommerundersøgelsen havde færdes alene i centrum om natten, mens det drejede sig om godt $43 \%$ af dem, der deltog i efterårsundersøgelsen.

Deltagere, der ikke havde færdes alene, blev spurgt, om frygt for kriminalitet havde haft indflydelse på deres beslutning. Det viser sig, at godt $35 \%$ af de deltagere i sommerundersøgelsen, som ikke havde gået i centrum alene om natten, svarede, at frygten for kriminalitet havde haft betydning herfor, mens det i efterårsundersøgelsen drejer sig om kun 26\% $(\mathrm{p}<0.05)$. Der sker altså en klar mindskning $\mathrm{i}$ andelen, der bevidst afholder sig for at færdes alene ude om natten som følge af frygt for kriminalitet.

Hvad er det så, der forårsager de ændringer, der finder sted mellem de to undersøgelser? Som nævnt har vi analyseret Morgunbladids omtale af begivenheden i Reykjaviks centrum, og resultaterne heraf ses på figur 2.

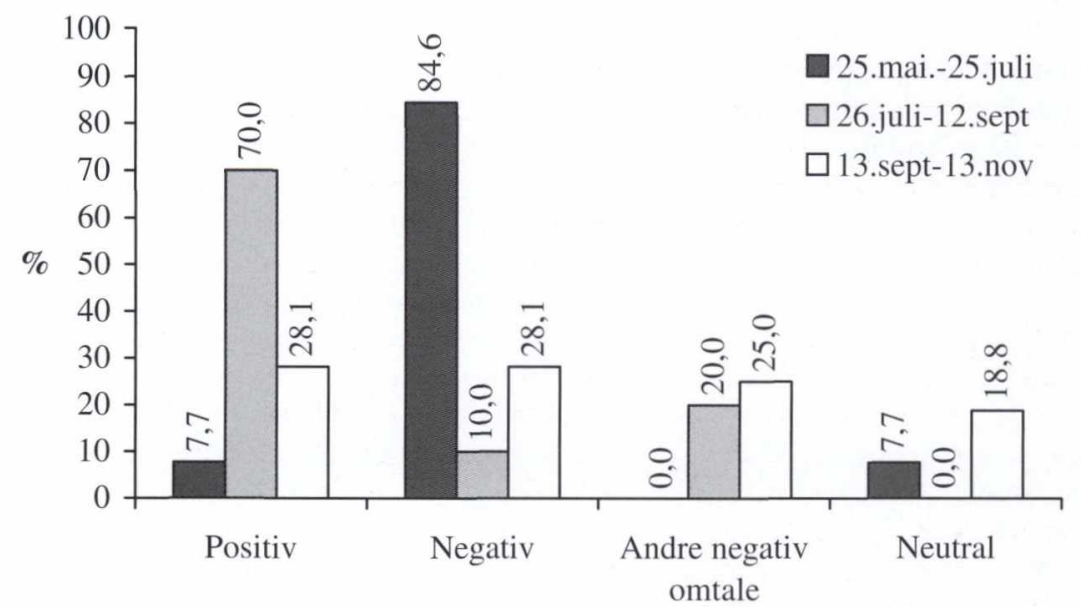

Figur 2. Morgunbladids artikler om begivenheder i Reykjaviks centrum fordelt efter periode og tendens. Procent.

I hele perioden bragte Morgunbladid 39 artikler om Reykjaviks centrum, 13 i perioden omkring den første undersøgelse, 10 mellem undersøgelserne og 16 omkring tidspunktet for den sidste undersøgelse. Figur 2 viser fordelingen af positive og negative artikler i hele perioden. Da den første undersøgelse fandt sted, var knap $85 \%$ af artiklerne forbundet med negativ omtale af forbrydelser. 
Denne gruppe udgjorde en meget mindre procentdel af artiklerne mellemde to undersøgelser $(10 \%)$ og kun $28 \%$ i perioden omkring den sidste undersøgelse. Hvad angår positive artikler, var kun $8 \%$ af omtalen af Reykjaviks centrum i denne kategori, da den første undersøgelse blev foretaget, men hele $70 \%$ af artiklerne fra perioden mellem undersøgelserne og $28 \%$, da den sidste undersøgelse fandt sted. Da den førsteundersøgelse blev foretaget, karakteriseredes debatten omkring midtbyen således for en stor del af negativ opmærksomhed omkring forbrydelser. Senere har denne debat aftaget, og andre emner er kommet i fokus.

\section{Diskussion}

Resultaterne viser, at beboernes tryghedsfølelse i midtbyen er steget betydeligt mellem de to undersøgelser, og at flere beboere i Reykjavik havde færdes alene om natten i efterårs- end i sommerundersøgelsen. Ligeledes viste undersøgelsen en betydelig mindskning $\mathrm{i}$ antallet, der mente, at frygt for kriminalitet var medvirkende til, at de ikke færdedes alene i midtbyen om natten. Denne ændring kan ifølge oplysninger fra politimesteren i Reykjavik ikke forklares med ændringer i antal forbrydelser, men må søges i andre forhold (Reykjaviks Politimester, 2002). Massemediernes omtale af begivenheder i Reykjaviks centrum ændredes mærkbart i denne periode, idet antallet af negative nyheder fra midtbyen mindskedes betydeligt, og det er ikke usandsynligt, at denne ændring har haft indflydelse på beboernes tryghedsfølelse og for frygt for kriminalitet. I sommeren 2001 foregik en heftig debat om voldshandlinger i midtbyen, og massemedierne fokuserede meget på denne bydel og den påståede midtbyproblematik. Debatten var yderst negativ og drejede sig bl.a. om de enorme menneskemængder, der samledes om natten i weekenderne. "Forpligtelse at svare befolkningen med en tryggere midtby", (Morgunblaдid, 2001b), om restauranternes lukketider. "Problemet i midtbyen”, (Morgunbladid, 2001c), åbning af de første striptease restauranter og samt om forskellige voldshandlinger, "Grove voldshandlinger øger” (Morgunbladid, 2001a). I denne forbindelse kan det også nævnes at et af dagbladene henvendte sig til den ene af os og bad om en artikel om denne problematik, som også blev skrevet (Gunnlaugsson, 2001).

Der er undersøgelser, der viser, at beboeres vurdering af sandsynligheden for at blive offer for en forbrydelse generelt er realistisk (Stafford og Galle, 1984). Denne undersøgelse støtter derimod den konklusion, at massemediernes omtale kan have indflydelse på beboeres tryghed, på deres færden og på frygt for kriminalitet. Påvirkningerne er ikke lige stærke på alle og sandsynligvis ikke langvarige, men efter alt at dømme dog til stede. Alligevel kan man ikke udelukke andre faktorer. Det påpegedes for nyligt i en artikel i Nordisk Tidsskrift for Kriminalvidenskab, at terrorangrebet på USA muligvis havde haft indflydelse på menneskers dagligdags bekymringer, der var trådt noget $\mathrm{i}$ baggrunden $\mathrm{i}$ forhold til den dramatiske begivenhed i USA (Clausen, 2002a). Præcis som det skete i 
Reykjavik, dalede bekymring for vold og kriminalitet således hos befolkningen i Danmark efter begivenhederne i USA. Disse resultater kalder således på flere undersøgelser for bedre at kunne vurdere, hvad der påvirker vor tryghed, og for at kunne vurdere forbindelsen mellem forbrydelser, massemediernes omtale og beboernes tryghed og frygt for kriminalitet.

Litteratur:

Balvig, Flemming (1990). Fear of Crime in Scandinavia - New Reality, New Theory? I Annika Snare (ed.) Criminal Violence in Scandinavia. Scandinavian Studies in Criminology. Vol. 11. Oslo: Norwegian University Press.

Clausen, Susanne (2002a). "Terrorangrebet på USA og bekymring for kriminalitet". Nordisk Tidsskrift for Kriminalvidenskab 89, Nr. 1: 16-26.

Clausen, Susanne (2002b). "Terrorangrebet på USA og danskernes bekymring for vold og kriminalitet”. NSfK's 44:e forskarseminarium Skeviks Gård/Stockholm, 2002, pp 77-83. Nordiska Samarbeidsrådet för Kriminologi.

Clemente, Frank og Michael Kleiman (1976). "Fear of Crime Among the Aged". Gerontologist 16:207-210.

Ferraro, Kenneth F. (1995). Fear of Crime: Interpreting Victimization Risk. Albany: State University of New York Press.

Gunnlaugsson, Helgi (1996). "Empiri og ideologi: Den objektive og subjektive siden av kriminaliteten i Island". Nordisk Tidsskrift for Kriminalvidenskab 83, Nr. 1: 14-26.

Gunnlaugsson, Helgi (2001). "Ólæti í mizborginni” (Ballade i midtbyen). DV, 25. juni 2001: 14.

Lewis, Dana A. og Greta Salem (1986). Fear of Crime: Incivility and the Production of a Social Problem. New Brunswick, N.J.: Transaction Books.

Morgunbladid, (2001a). "Grófum líkamsmeidingum fjölgar” (Grove voldshandlinger øger). 12. juli 2001.

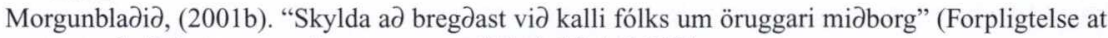
svare befolkningen med en tryggere midtby). 19. juli 2001.

Morgunbladid, (2001c). "Vandinn í mizborginni” (Problemet i midtbyen). 21. juli 2001.

Ollenberger, Jane C. (1981). "Criminal Victimization and Fear of Crime". Research on Aging 3:101118.

Rosenbaum, Dennis P. og Linda Heath (1990). "The "Psycho-Logic" of Fear-Reduction and CrimePrevention Programs". In John Edwards et. al., eds., Social Influence Processes and Prevention. New York: Plenum pp. 221-247.

Reykjaviks Politimester (2002). Årsrapport 2001. Reykjavik: Politimesteren.

Skogan, Wesley G. og M.G. Maxfield (1981). Coping with Crime: Individual and Neighborhood Reactions. Beverly Hills, Calif.: Sage.

Stafford, Mark C. og Omar R. Galle (1984). "Victimization Rates, Exposure to Risk, and Fear of Crime". Criminology 22:173-185.

Zedner, L. (1997). Victims. I Mike Maguire, Rod Morgan \& Robert Reiner (eds.) The Oxford Handbook of Criminology, 2nd ed. Oxford: Clarendum Press. 
Adresse: Helgi Gunnlaugsson, Ph.D.

Islands Universitet

Sosiologi fakultet

101 Reykjavik

Island

e-post: helgigun@hi.is

Rannveig pórisdóttir, M.A.

Rigspolitichefen i Island

Skúlagata 21,

101 Reykjavík

Island

e-post: rannveig@rls.is 